"Mircea cel Batran" Naval Academy Scientific Bulletin, Volume XIX - 2016 - Issue 1

Published by "Mircea cel Batran" Naval Academy Press, Constanta, Romania /I The journal is indexed in:

PROQUEST / DOAJ / DRJI / JOURNAL INDEX / I2OR / SCIENCE LIBRARY INDEX / Google Scholar / Crossref /

Academic Keys / ROAD Open Access / OAJI / Academic Resources / Scientific Indexing Services / SCIPIO

\title{
THE MANAGERIAL BENEFITS AND LIMITATIONS OF BIODIESEL USAGE IN MARITIME TRANSPORTATION
}

\author{
Doru COSOFRET ${ }^{1}$ \\ Marian BUNEA ${ }^{2}$ \\ Catalin POPA ${ }^{3}$ \\ ${ }^{1}$ PhDc eng, Military Technical Academy, Bucharest \\ ${ }^{2}$ Prof. dr. eng, Military Technical Academy, Bucharest \\ ${ }^{3}$ Assoc. prof. dr. eng, „Mircea cel Batran” Naval Academy, Constanta
}

\begin{abstract}
The global economy development has not only positive effects but also negative consequences, in terms of air pollution with a major impact against the climate change and human health. This fact stimulated the intensification of research endeavours to identify and develop new options for sustainable energy supply and further for reducing the dependence on fossil fuels, as considered the major air pollutants globally. Among the non-polluting fuels, the currently biodiesel second generation becomes a viable solution in order to develop an alternative sustainable source of fueling. Even if this type of fuel has been implemented and approved as viable for land and air transportation meanings, the maritime transportation sector is still reluctant in implementing this new fuel on board to commercial vessels. In this article were approached the major advantages of using biodiesel powered engines, being detailed the technical, operational and legal solutions to eliminate the current reserve in adopting this innovative cleaner fuel on maritime transportation practice.
\end{abstract}

Keywords: Maritime transports, Biodiesel, Gas emissions, Sustainable transports.

\section{Introduction}

The International Maritime Organization (IMO), defined as the UN's body who regulates the international framework activities in seaborne trade, has enforced and since 201 , by Annex VI to Marpol, certain standards regarding the air pollution caused by the $\mathrm{NO}_{x}, \mathrm{SO}_{x}$ emissions and further particular energy efficiency standards, with the final purpose of decreasing gas emissions coming from burning conventional combustion version on board the maritime ships [6]. Following the imposed rules, the ships' management tries to implement various technical and operational measures to reduce the fuel consumption onboard the maritime vessels' as being the major option for reducing the gas emissions and the greenhouse effect, thus bringing the energy efficiency below the IMO imposed limits. Beside the fuel consumption measure the use of alternative fuels for marine engines renewable power has been targeted as well.

On the other hand, sustaining the importance of greenhouse gas emission importance, the European Union, due to Directive no. 2009/28 / EC provisions, as issued to stimulate the renewable energy implementation in different areas, has committed to reduce gas emissions till 2020 by $20 \%$ compared to 1990 and to improve the energy efficiency based on the use of biofuels in a quota of minimum $20 \%$, calculated as percentage of overall burned conventional fossil fuels [3].
Thus, analyzing all options among currently existing biofuels, the biodiesel is one of the most important option available for the sips' owners or operators both because of its close compatibility with the fossil fuels features and diesel engines technical requirements, as well as the market favorable conditions, due to its easy and cheap availability for different usage versions, including for road and air meaning of transportation $[1,7]$.

An overview of biodiesel properties

The American Society of Testing and Materials (ASTM) D-2 Committee has defined the biodiesel as "a compound consisting of monoalkyl esters of long chain fatty hydrocarbon acids, derived from renewable fat sources as vegetable oils and animal fats" [2].

The biodiesel is obtained by of triglyceride fats reaction against the methanol, in the presence of a strong basis as a catalyst (eg. $\mathrm{NaOH}, \mathrm{KOH}$ ), after which the methyl ester is formed by transesterification process. Consequently, in figure no. 1 is shown the chemical process of forming biodiesel $[5,10]$. Depending on the raw material used in the biodiesel manufacturing process, there are three generations of biodiesel: a) the first generation is produced from vegetable oils supply and wasted oils; b) the next generation is produced from non-food oils, and c) now the biodiesel third generation is made from animal fats scraps and from seaweed [5].

As shown in the picture bellow, the chemical structure is similar to that one of the classical 
"Mircea cel Batran" Naval Academy Scientific Bulletin, Volume XIX - 2016 - Issue 1

Published by "Mircea cel Batran" Naval Academy Press, Constanta, Romania /I The journal is indexed in: PROQUEST / DOAJ / DRJI / JOURNAL INDEX / I2OR / SCIENCE LIBRARY INDEX / Google Scholar / Crossref I Academic Keys / ROAD Open Access / OAJI / Academic Resources / Scientific Indexing Services / SCIPIO

fossil fuels, the biodiesel fuels having in addition the that two more oxygen atoms. The biodiesel's physical and chemical properties are similar to those of diesel fuel, which allows to be used in a efficient mixture with fossil fuels as to be used for diesel engines. Among these properties, the kinematic viscosity, the density and the calorific value are the most important parameters.

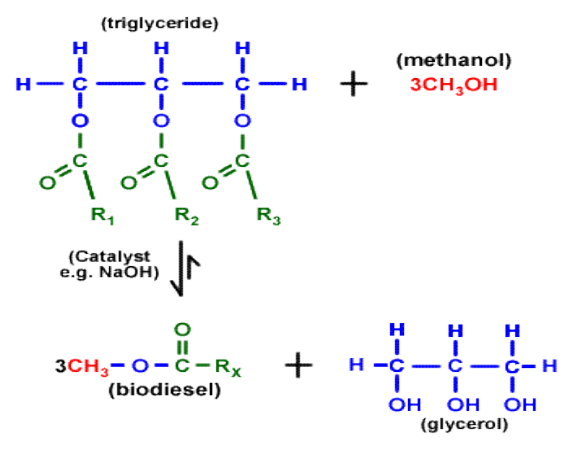

Figure 1. Trans-etherification process that affects the engine performance and the emission features $[15,18]$

In the Table 1 are presented the majpr properties of the biodiesel, comparing with the fossil fuels corresponsive properties [7].

\begin{tabular}{|c|c|c|c|}
\hline Propriety & $\begin{array}{c}\text { Biodiesel } \\
\text { EN } \\
14214\end{array}$ & $\begin{array}{c}\text { Marine } \\
\text { diesel } \\
\text { ISO } \\
8217 \\
\text { DMB }\end{array}$ & $\begin{array}{c}\text { Heavy } \\
\text { Fuel Oil } \\
\text { ISO } \\
8217 \\
\text { RM .. }\end{array}$ \\
\hline $\begin{array}{l}\text { Density } / 15^{\circ} \mathrm{C} \\
{\left[\mathrm{kg} / \mathrm{m}^{3}\right]}\end{array}$ & $860-900$ & $<900$ & $\begin{array}{l}975- \\
1010\end{array}$ \\
\hline $\begin{array}{l}\text { Viscosity at } 40 \\
{ }^{\circ} \mathrm{C} / 50^{\circ} \mathrm{C} \text { [cSt] }\end{array}$ & $3.5-5$ & $<11$ & $\begin{array}{l}<700 \\
150 \mathrm{C}\end{array}$ \\
\hline Cetane no. & $>51$ & $>35$ & $>20$ \\
\hline Flash point $\left[{ }^{\circ} \mathrm{C}\right]$ & $>120$ & $>60$ & $>60$ \\
\hline Ash content [\%] & $<0.01$ & $<0.01$ & $<0.2$ \\
\hline $\begin{array}{l}\text { Water content } \\
\text { [ppm] }\end{array}$ & $<500$ & $<300$ & $<5000$ \\
\hline Acid no. (TAN) & $<0.5$ & - & - \\
\hline $\begin{array}{l}\text { Sulphur content } \\
\text { [ppm] }\end{array}$ & $<10$ & $\begin{array}{ll}< & 20 \\
000 & \\
\end{array}$ & $\begin{array}{l}<50 \\
000\end{array}$ \\
\hline $\begin{array}{l}\text { Calorific value } \\
{[\mathrm{MJ} / \mathrm{kg}]}\end{array}$ & ca. 37.5 & са. 42 & ca. 40 \\
\hline
\end{tabular}

The biodiesel advantages in maritime industry A large number of studies presented are often asserting based on their results the benefits of biodiesel compared with the conventional fuels, respectively: better lubrication, excellent biodegradability, high combustion efficiency and reduced gas emissions.
The lower calorific value, its viscosity and the greater density compared to the diesel adversely affect engine performance (low power, increased fuel consumption, etc.). But, mixed with marine fuel at a rate of up to $50 \%$, the engine performance does not change significantly. For example, for a mixture of $20 \%$ biodiesel within diesel, the calorific value will be decreased by approximately $1.9-2.7 \%$ compared to the calorific value of the simple diesel fuel [14]. In case of residual marine fuels, a mixture thereof with $20 \%$ biodiesel, has determined a caloric decrease of $1.9 \%$ for diesel fuel and with $0.1 \%$ for heavy diesel fuels [7]. Therefore, if case of mixing the marine fuel with $20 \%$ biodiesel, the engine will not record an insignificant drop in power. This stance owes to the fact that the biodiesel even lower in its heating value compared to the fossil fuels'caloric power, is still releasing a better burning power in engine combustion, due to its addition two oxygen atoms within chemical composition.

Regarding gas emissions, the wide majority of the literature mentions significant reductions in emissions of $\mathrm{CO}_{2}, \mathrm{CO}, \mathrm{SO}_{x}$ and $\mathrm{PM}$, depending on the concentration of biodiesel in fossil fuels, due to a more efficient combustion as recorded in practice. [9,13, 15,17].

Regarding the NO emissions most if the undertaken researches have reported that the usage of biodiesel as main fuel for the engines, leads to an emissions of NO increment in ratio with the diesel fed engines due to the increased injection leading (as ignition and combustion are earlier initiated in the burning cycle), determined by the superior physical properties of the biodiesel compared to the diesel in regard of its viscosity, density , and oxygen content $[9,12,17]$.

In the case of naval engines, the increased emissions of $\mathrm{NO}$ can be controlled by cooling the air supply system of the engine, which extent the combustion time and compressing the burning temperature in the combustion chamber. Also, in case of engine endowed with the electronic control, exhaust valve injection and variable injection timings (VIT) the NO emissions are controlled and limited within the allowed range of values. This electronic system calculates the optimal solution for injection and exhausting so as to achieve the optimum for the combustion process, both from the point of view of fuel consumption and NO reduced emissions [16].

An operational method to reduce the $\mathrm{NO}$ emissions from ships is to decrease the engine propelling load, which will consequently reduce the combustion temperature and the fuel consumption regime. Although there were many practical experiences of onboard biodiesel usage on maritime vessels, similarly with automotive 
"Mircea cel Batran" Naval Academy Scientific Bulletin, Volume XIX - 2016 - Issue 1

Published by "Mircea cel Batran" Naval Academy Press, Constanta, Romania /I The journal is indexed in: PROQUEST / DOAJ / DRJI / JOURNAL INDEX / I2OR / SCIENCE LIBRARY INDEX / Google Scholar / Crossref I Academic Keys / ROAD Open Access / OAJI / Academic Resources / Scientific Indexing Services / SCIPIO

diesel engines applications, it can be stated that the results were good, this type of fuel proving compatible with the ship propelling requirements, its integration on-board being reasonable manageable and technically reliable.

In terms of technical integration, the mixtures of biodiesel with MDO/MGO in small shares (up to $20 \%$ ) in case of naval engines supply, seems to be the most promising fuel for the near future of the maritime transport, due to a better compatibility with the existing range of engines, including the supply and storage techniques on board $[1,11]$.

As regards the economic and social impacts on large scales of biodiesel usage, that will provide new business opportunities and, further new jobs, especially in agriculture and, further, in its production and distribution logistic systems [7]. As stimulated to be used on economy of scales level, the whole supply chain for reverse logistic system will be stimulated, in order to collect and to produce the biofuel.

\section{The managerial limits in biodiesel usage onboard to maritime ships}

Today the most relevant parameters that limit the potential use of biodiesel in maritime shipping are the following: the availability, technological development, technical integration and operational consequences.

In terms of availability, at the present, there is no proper developed market for biofuels yet, supported by an efficient supply chain system connected to the international maritime transport supply system, in addition to the existent market barriers. The major barrier nowadays is the market biofuel production cost that is still higher than the cost for the fossil marine fuels that makes it not attractive to the ship operators, because the biodiesel would finally considerably increase the operating costs of the vessels. Also, the biofuels introduction in the maritime transportation represents a threat for the existing fossil fuels' market players, which have a stronger consolidated position in the supply chain and fuels' distribution system. This is because in case of biodiesel usage, as literature shows, the ship owners would be able to produce the biofuels on board or have the potential to onset a cooperation framework with the new suppliers of marine biofuels market [1].

Regarding the implementation of large-scale biodiesel technology on board the ships, at the present, there are still several uncertainties, as there is no major experience of their usage in the marine engines yet. There are only several initiatives coming from some private companies, who have investigated the existing options for the implementation of operational biodiesel onboard the ships, but their results are not available yet for the general public [1].

The overtaken researches conducted on automotive diesel engines, have shown that biodiesel is more oxidant than gas for those components made from specific materials such as bronze, brass, copper, lead, tin or other elastomers. It has also been found that aluminum and stainless steel alloys do not oxidize in contact with biodiesel [4]. Therefore, in order to implement the biodiesel on board the maritime vessels in service, the compounding materials should be taken into account when are coming as engine parts working in contact with biodiesel (e.g. piston, cylinder head, valve or injector). In the same respect, the rubber hoses and the engine's fuel supplying system should be made from fluoroelastomer (corrosion resistant rubber).

The significant viscosity and high density of biodiesel compared to the diesel used values is another impediment to its implementation on board, due to the clogging fuel injectors and filters [4]. To improve the biodiesel's viscosity and density is recommended first, the implementation of on engine pre-heating systems (the ship should be endowed with specific designed facilities for fuel pre-heating, especially when the engine is feeding with the residual fuel, type IFO) and, secondly, the usage of biodiesel and diesel oil mixtures onboard the ships. [14]

But the major disadvantage regarding the biodiesel implementation onboard to maritime vessels is related to its storage particularities, very often invoked as a major counterargument to those who are not interested about this fueling option. It is considered that during prolonged storage of biofuels on board, their quality will be degraded by micro-organisms development, by biofuel acidity increment due to the condensed water, as well as by the degradation of its fluidity properties at low temperatures. These counterarguments are coming from a lack of knowledge regarding the biofuels usage particularities in practice, since the existing data in the literature and the current researches have failed to prove and to scientifically support these technical restrictions. For example, within a conducted by Maersk Company with Lloyds Register, spanning a period of 6 months, there were not detected any bacterial clusters formed in the storage tanks, when biofuels had been used on board [1].

Even if these restrictions would be viable, it could be managed onboard the ships by taking managerial measures, such as: the biodiesel storage in properly cleaned tanks designed for this purposes, the fuels' storage on limited span time on board the ships, optimizing the voyage 
"Mircea cel Batran" Naval Academy Scientific Bulletin, Volume XIX - 2016 - Issue 1

Published by "Mircea cel Batran" Naval Academy Press, Constanta, Romania /I The journal is indexed in: PROQUEST / DOAJ / DRJI / JOURNAL INDEX / I2OR / SCIENCE LIBRARY INDEX / Google Scholar / Crossref / Academic Keys / ROAD Open Access / OAJI / Academic Resources / Scientific Indexing Services / SCIPIO

duration, the issuance of clear specifications regarding the recommended percentage of biodiesel mixture with marine fuels used onboard and proper procedures implementation for monitoring biodiesel's physical and chemical properties.

\section{CONCLUSIONS}

The shipping industry is currently in a state of guidance seeking optimal solution for biodiesel implementation on board to maritime ships, facing a wide array of uncertainties both on technical and economic perspectives, with a great impact against managerial instruments used in fleet operation.

These uncertainties may be overcame by creating and implementing suitable policies and supporting financing schemes for implementing biofuels supplying systems onboard to commercial vessels (e.g. green certificates approval or subsidy financial support for companies). Also, where not voluntary agreed, it will be to useful to tighten the legislation regarding the $\mathrm{NO}_{x}$ emissions exhausted by commercial ships, based on IMO clear standards issuance. When voluntary, is very useful to inform the shipowners and the public about the positive effects of biofuels usage, through a better sharing of the experimental results conducted by the marine engines manufacturers or conveying good practice examples as coming from the ship operators.

Thinking about economic perspective it is further very important to reduce the biofuels' production costs, by using raw materials as available in large scale and implementing an efficient supply chain for this fuel similar to the conventional supplying chain. The maritime industry and the ship managers should look in the future, following the automotive industry successful story in respect of biodiesel usage, as a prove for the alternative energy systems options viability and advantages, in order to promote the sustainable development principles toward a green transportation system.

\section{BIBLIOGRAPHY}

[1] Anouk Florentinus, Cuijpers, Carlo Hamelinck, Arno van den Bos, Rob Winkel Maarten. Potential of biofuel for shiping.Final report European Maritime Safety Agency (EMSA). Ecofys project; ianuary 2012. HYPERLINK http://www.ecofys.com/files/files/ecofys 2012 potential of biofuels in shipping 02.pdf.\%20 http://www.ecofys.com/files/files/ecofys 2012 potential of biofuels in shipping 02.pdf. [2] ASTM. Specifications Related to Diesel/Compression Ignition Fuels http://www.astm.org/COMMIT/D02\%20New\%20Specifications\%20Forum\%20Summary.pdf [3]Comission, European. Directiva 2009/28/CE, HYPERLINK

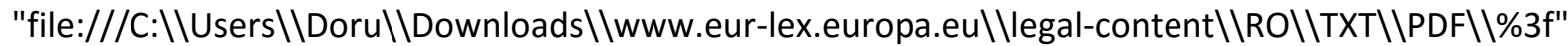
www.eur-lex.europa.eu/legal-content/RO/TXT/PDF/?

[4] Cursaru Diana, Sonia Mihai. Corrosion Behaviour of Automotive Materials in Biodiesel from Sunflower Oil, Revista de chimie, vol. 63, No. 9 , 2012, Bucuresti.

[5] Deliu C - CG.6 Combustibili, 2013, http://www.deliu.ro/mod/folder/view.php?id=212

[6] IMO. Resolution MEPC.203(62). Amendments to the annex of the protocol of 1997 to amend the international convention for the prevention of pollution from ships, 1973, as modified by the protocol of 1978 relating thereto. London s.n. 2011.

[7] Kjeld Aabo. Alternative brændstoffer og røgrensning, South America Seminars 2009.

[8] Lin, Cherng-Yuan. Effects of Biodiesel Blend on Marine Fuel Characteristics for Marine Vessels. Journal Energies. www. mdpi.com/journal/energies, 2013, Vol. 6, pp. 4945-4955.

[9] Nantha Gopa K.I, Arindam Pal, Sumit Sharma, Charan Samanchi. Investigation of emissions and combustion. Alexandria Engineering Journal, 2014, Vol. 53, pp. 281-287.

[10] Prakash R., R.K. Singh and S. Murugan. Comparison of Performance and Emission Parameters of a Diesel Engine Fueled with Biodiesel and Wood Pyrolysis Oil Emulsions. International Energy Journal, 2012, Vol. 13, pp. 123-132.

[11] Ralph McGill et al. Alternative Fuels for Marine Applications. A Report from the IEA Advanced Motor Fuels Implementing Agreement. 2013.

[12] Sharma S.K., Ankur Dixit , Priyanka Goyal, S.Maheshwari. A Techical Review of Biodiesel Fuel Emissions and Performance on Industrial and Automobiles Application.. International Journal Of Modern Engineering Research (IJMER) | Vol. 4, Iss.11, 2014.

[13] Shirneshan Alireza, Morteza Almassi, Barat Ghobadian, Ali Mohammad Borghei, Gholam Hassan Najafi. Effects of Biodiesel and Engine Load on Some Emission Characteristics of a Direct Injection Diesel Engine.Current World Environment, 2012,Vol. 7(2), pp. 207-212

[14] Tesfa, B., et al. Prediction models for density and viscosity of biodiesel and their effects on fuel supply system in Cl engines. s.I. : Renew. Energy, 2010, Vol 35, pp. 2752-2760. 
"Mircea cel Batran" Naval Academy Scientific Bulletin, Volume XIX - 2016 - Issue 1

Published by "Mircea cel Batran" Naval Academy Press, Constanta, Romania // The journal is indexed in: PROQUEST / DOAJ / DRJI / JOURNAL INDEX / I2OR / SCIENCE LIBRARY INDEX / Google Scholar / Crossref I Academic Keys / ROAD Open Access / OAJI / Academic Resources / Scientific Indexing Services / SCIPIO

http://eprints.hud.ac.uk/7659/1/Belachew_Renewable_Jour.pdf.

[15] Tesfa Belachew, Fengshou Gu, Rakesh Mishra and Andrew Ball. Emission Characteristics of a Cl Engine Running with a Range of Biodiesel Feedstocks,Energies 2014, Vol.7, pp. 334-350;

www.mdpi.com/journal/energies

[16] Trifan A., OLaru N. Instalații energetice cu motoare de ardere interna. Tehnologii de reducere a mediului marin. Constanta : Ed Academiei Navale Mircea cel Batrin, 2010. pp. 222, ISBN 978-973-1870-76-2.

[17]. Xue, J., Grift, T.E. și Hansen, A.C. Effect of biodiesel on engine performances and emissions. s.I. : Renew. Sustain. Energy Rev. 2011, Vol.15, pp. 1098-1116.

[18]. ${ }^{* * *}$. http://biofuelsystems.com/biodiesel-chemistry.html 